\title{
MBTD1 wt Allele
}

National Cancer Institute

\section{Source}

National Cancer Institute. MBTD1 wt Allele. NCI Thesaurus. Code C111975.

Human MBTD1 wild-type allele is located in the vicinity of $17 q 21.33$ and is approximately $83 \mathrm{~kb}$ in length. This allele, which encodes MBT domain-containing protein 1, may be involved in transcriptional regulation. A fusion of this gene and the CXorf67 gene may be associated with low-grade endometrial stromal sarcomas. 